\title{
Hemagglutinating/Hemolytic activities in extracts of marine invertebrates from the Brazilian coast and isolation of two lectins from the marine sponge Cliona varians and the sea cucumber Holothuria grisea
}

\author{
RANIERE M. MOURA ${ }^{1}$, ARTHUR A. MELO ${ }^{2}$, RÔMULO F. CARNEIRO ${ }^{2}$ CÍCERA R.F. RODRIGUES $^{3}$, \\ PLÍNIO DELATORRE $^{4}$, KYRIA S. NASCIMENTO ${ }^{5}$, SILVANA SAKER-SAMPAIO ${ }^{2}$, \\ CELSO S. NAGANO ${ }^{2}$, BENILDO S. CAVADA ${ }^{5}$ and ALEXANDRE H. SAMPAIO ${ }^{2}$ \\ ${ }^{1}$ Universidade Potiguar, Escola de Medicina, Av. Sen. Salgado Filho, \\ 1610, Lagoa Nova, 59054-000 Natal, RN, Brasil \\ ${ }^{2}$ Laboratório de Bioquímica Marinha/BioMar-Lab, Departamento de \\ Engenharia de Pesca, Universidade Federal do Ceará, Campus do Pici, \\ Av. Humberto Monte, s/n, Bloco 871, 60440-970 Fortaleza, CE, Brasil \\ ${ }^{3}$ Faculdade Leão Sampaio, Av. Maria Letícia Leite Pereira, \\ s/n, 63040-405 Juazeiro do Norte, CE, Brasil \\ ${ }^{4}$ Departamento de Biologia Molecular, Universidade Federal da \\ Paraíba, Cidade Universitária, Av. Contorno da Cidade \\ Universitária, 167, 58051-900 João Pessoa, PB, Brasil \\ ${ }^{5}$ Laboratório de Moléculas Biologicamente Ativas/BioMol-Lab, Departamento de \\ Bioquímica e Biologia Molecular, Universidade Federal do Ceará, Campus do Pici, \\ Av. Humberto Monte, s/n, Bloco 907, 60440-970 Fortaleza, CE, Brasil
}

Manuscript received on August 5, 2014; accepted for publication on November 28, 2014

\begin{abstract}
Twenty species of marine invertebrates from the Brazilian coast were screened for hemagglutinating/ hemolytic activity. In at least twelve tested species, hemagglutinating activity was different for different blood types, suggesting the presence of lectins. Extracts from four species showed hemolytic activity. Two new lectins were purified from the marine sponge Cliona varians (CvL2) and sea cucumber Holothuria grisea (HGL). CvL-2 was able to agglutinate rabbit erythrocytes and was inhibited by galactosides. The hemagglutinating activity was optimal in $\mathrm{pH}$ neutral and temperatures below $70{ }^{\circ} \mathrm{C}$. CvL-2 is a trimeric protein with subunits of $175 \mathrm{kDa}$. On the other hand, HGL showed both hemagglutinating and hemolytic activity in human and rabbit erythrocytes, but hemolysis could be inhibited by osmotic protection, and agglutination was inhibited by mucin. $\mathrm{HGL}$ was stable in $\mathrm{pH}$ values ranging from 4 to 10 and temperatures up to $90^{\circ} \mathrm{C}$. In electrophoresis and gel filtration, HGL was a monomeric protein with $15 \mathrm{kDa}$. CvL-2 and HGL showed different levels of toxicity to Artemia naplii. CvL-2 showed $\mathrm{LC}_{50}$ of $850.1 \mu \mathrm{g} / \mathrm{mL}$, whereas HGL showed $\mathrm{LC}_{50}$ of $9.5 \mu \mathrm{g} / \mathrm{mL}$.
\end{abstract}

Key words: purification, hemolysis, cytotoxicity, galactose.

Correspondence to: Alexandre Holanda Sampaio

E-mail: alexholandasampaio@gmail.com 


\section{INTRODUCTION}

Marine biodiversity is the result of a long evolutionary history and extreme environmental conditions of pressure, light, oxygen, and temperature, giving rise to organisms with unique features (Ritchie et al. 2013). Marine life is much older than earthly life and has been evolving and diversifying longer (Burgess 2012). This amazing, but understudied, species diversity has provided a huge variety of molecules with biotechnological applications. Many of these compounds, which have already been isolated and studied, belong to marine invertebrates, such as sponges, cnidarians, mollusks, arthropods, echinoderms and tunicates (Rasjasa et al. 2011). Among these compounds are proteins (Pajic et al. 2002, Yoshida et al. 2007) and secondary metabolites (Kuramoto et al. 2004, Sipkema et al. 2005) with a wide range of biological activities.

Lectins are a group of carbohydratebinding proteins found in a wide range of organisms, including viruses, bacteria, fungi, plants, and animals. Lectins are involved in various biological functions, such as host defense, cell-cell interaction and folding of glycoproteins (Kilpatrick 2002, Sharon and Lis 2004). Lectins from marine organisms are one of the promising candidates for useful therapeutic agents because carbohydrate structures, such as proteoglycans, glycoproteins, and glycolipids, have been implicated in certain cell types, and their physiological and pathological functions include host-pathogen interactions and cell-cell communication (Ogawa et al. 2011).

In particular, marine invertebrate lectins have attracted great interest due to their biotechnological properties. For instance, a lectin isolated from the sea cucumber Cucumaria echinata (CELIII) was expressed in transgenic mosquitoes and impairs the development of the Malaria parasite (Yoshida et al. 2007). Lectins isolated from the marine sponges Haliclona cratera and Craniella australiensis displayed cytotoxic effect against malignant cells and mitogenic response towards BALB/c splenocytes, respectively (Pajic et al. 2002, Xiong et al. 2006).

The growing applications of lectins underscore the potential economic importance of the discovery of novel species for biotechnology. To date, the tropical sponge Cliona varians possesses one isolated lectin, $\mathrm{CvL}-1$. CvL-1 is a galactose-binding lectin with cytotoxic effect on pathogenic bacteria, such as Bacillus subtilis and Staphylococcus aureus (Moura et al. 2006). Furthermore, the sea cucumber Holothurea grisea possesses two isolated lectins: $\mathrm{HGA}$, an anti-inflammatory lectin of $228 \mathrm{kDa}$, and HGA-2, a C-type lectin of $34 \mathrm{kDa}$ (Moura et al. 2012, Melo et al. 2014). In the present work, we screened twenty Brazilian species of marine invertebrates for their hemagglutinating/hemolytic activity, and found two new lectins isolated from $C$. varians and $H$. grisea.

\section{MATERIALS AND METHODS}

\section{ANIMAL COLLECTIONS}

Marine sponges Amphimedon viridis, Callyspongia sp., Haliclona caerulea, Haliclona melana, and the sea urchin Echinometra lucunter were collected at Pacheco Beach, Caucaia, state of Ceará, Brazil.

Specimens of the marine sponge Aplysina fulva, cnidarians Protopalythoa variabilis and Zoanthus sociatus, mollusks Ischinachiton pectinatus, Littorina ziczac, Pleuropoca sp., Turbinella laevigata, and, Voluta ebrea and the sea cucumber Holothuria arenicola were collected at Paracuru Beach, São Gonçalo, Ceará State, Brazil.

Specimens of marine sponges Aaptos sp., Haliclona manglaris and Spongorites sp., were collected in Icaraí Beach, Amontada, state of Ceará, Brazil.

The decapods Callinectes danae were collected at Barra do Ceará Beach, Fortaleza, state of Ceará, Brazil. 
Specimens of the marine sponge Cliona varians and the sea cucumber Holothurea grisea were collected at Santa Rita Beach, state of Rio Grande do Norte, Brazil.

The animals were transported in a thermal box at $4{ }^{\circ} \mathrm{C}$ and then stored at $-20^{\circ} \mathrm{C}$ until use. All collections were performed on sunny days, when water temperature was between $25^{\circ} \mathrm{C}$ and $27^{\circ} \mathrm{C}$.

\section{Preparation OF AQUEOUS EXTRACTS}

Marine sponges were triturated in grail and homogenized in Tris buffer $50 \mathrm{mM}, \mathrm{pH}$ 7.6, containing $\mathrm{NaCl} 150 \mathrm{mM}$ and $\mathrm{CaCl}_{2} 20 \mathrm{mM}$ (TBS/ $\left.\mathrm{Ca}^{2+}\right)$ at a ratio of $1: 2(\mathrm{w} / \mathrm{v})$. The mixtures were filtered and centrifuged at $8000 \mathrm{xg}$ for $20 \mathrm{~min}$ at $4{ }^{\circ} \mathrm{C}$. Supernatants were stored at $-20{ }^{\circ} \mathrm{C}$ until use.

The cnidarians were freeze-dried and triturated until a fine powder was obtained. The powders were homogenized in TBS/ $\mathrm{Ca}^{2+}$ at a ratio of 1:2 (w/v). The mixtures were filtered and centrifuged at 8000 $\mathrm{xg}$ for $20 \mathrm{~min}$ at $4{ }^{\circ} \mathrm{C}$. The supernatants were stored at $-20^{\circ} \mathrm{C}$ until use.

The mollusks and echinoderms Holothurea grisea and $H$. arenicola were cut into small pieces, triturated in mortar and pestle, homogenized in $\mathrm{TBS} / \mathrm{Ca}^{2+}$ and filtered. After centrifugation, supernatants were stored at $-20{ }^{\circ} \mathrm{C}$ until use.

Specimens of Echinometer lucunter were maintained on ice until dead for inanition. Then, peristomial membrane was cut around the mouth and the Aristotle's lantern was removed, and the celomatic plasma was collected by pipetting. The coelomic plasma was allowed to clot for $1 \mathrm{~h}$ at $0{ }^{\circ} \mathrm{C}$. The supernatants were stored at $-20{ }^{\circ} \mathrm{C}$ until use.

The swimming crabs $C$. danae averaging $5 \mathrm{~cm}$ in length were maintained in ice. The hemolymph was collected from the cheliped using a sterile syringe, and allowed to clot for $1 \mathrm{~h}$ at $0{ }^{\circ} \mathrm{C}$. The supernatants were stored at $-20^{\circ} \mathrm{C}$ until use.

Crude extracts were used within three months after preparation.
HEMAGGLUTINATING/HEMOLYTIC AND INHIBITION ASSAYS

The hemagglutinating/hemolytic activities were assayed in microtiter V plates (Nunc, Denmark) as described by Sampaio et al. (1998). Native blood cells (Human ABO and rabbit erythrocytes) were treated with papain and trypsin. One hemagglutinating unit (HU) was defined as the reciprocal of the highest dilution giving positive hemagglutination. Hemolytic activity was examined by visual examination of lysis of the erythrocytes under conditions similar to those of the hemagglutination assay.

Purified lectins were submitted to inhibition assay as described by Sampaio et al. (1998). The following carbohydrates and glycoproteins were used: D-galactose, D-glucose, D-mannose, D-fructose, D-arabinose, $N$-acetyl-D-glucosamine, $N$-acetyl-Dgalactosamine, methyl- $\alpha$-D-glucopyranoside, methyl- $\alpha$-D-galactopyranoside, D-lactose, D-fructose, D-sucrose, D-lactulose, porcine stomach mucin (PSM), fetuin, tyroglobulin, ovomucoid, and orosomucoid. The initial concentrations were $100 \mathrm{mM}$ or $5 \mathrm{mg} / \mathrm{mL}$ for sugars and glycoprotein, respectively.

In the assay using the lectin purified from Holothuria griea, erythrocytes were osmotically protected. Hemagglutinating activity was evaluated in the presence of dextrose $5.5 \%$.

\section{PURIFICATION OF HotothURIa GRISEA HEMOLYTIC}

LeCTIN (HGL)

Specimens of $\mathrm{H}$. grisea were cut into small pieces. The pieces were washed in distilled water and freeze-dried. Pieces were then triturated in mortar and pestle and extracted at a ratio of 1:2(w/v) with $0.05 \mathrm{M}$ Tris- $\mathrm{HCl}$ buffer $\mathrm{pH} 7.6$ containing $\mathrm{NaCl}$ $0.15 \mathrm{M}$ (TBS) for $2 \mathrm{~h}$ at room temperature. After centrifugation for $30 \mathrm{~min}$ at $8000 \mathrm{xg}$ at $4{ }^{\circ} \mathrm{C}$, the supernatant (crude extract) was partitioned with n-butanol $50 \%$ and ethanol $75 \%$ and then precipitated with acetone at 2.0 vol. The supernatant (F2) was dried in a vacuum concentrator and solubilized in a small volume of TBS. After centrifugation, F2 was 
applied to a TSK gel G3000SWXL $(1.28 \times 30 \mathrm{~cm})$ column coupled to an ÄKTA purifier system. The column was equilibrated and eluted with TBS at a flow rate of $1 \mathrm{~mL} / \mathrm{min}$. Chromatography was monitored at $280 \mathrm{~nm}$, and $1 \mathrm{~mL}$ fractions were collected.

PURIFICATION OF CLIONA VARIANS LECTINS (CVL-1 AND CVL-2)

C. varians crude extract was prepared as described above. The crude extract was precipitated with acetone at 1.0 vol. After centrifugation, the pellet was recovered with $0.05 \mathrm{M}$ Tris buffer, $\mathrm{pH} 7.0$, containing $1 \mathrm{M}\left(\mathrm{NH}_{4}\right)_{2} \mathrm{SO}_{4}$ (Tris/ $\left.\left(\mathrm{NH}_{4}\right)_{2} \mathrm{SO}_{4}\right)$. This $\mathrm{CvL}$ - -enriched fraction showed a higher level of hemagglutinating activity to rabbit trypsin-treated erythrocytes. CvL- -enriched fraction was then applied on Phenyl-Sepharose 6B column (1.0 x 6.0 $\mathrm{cm})$ previously equilibrated with Tris/ $\left(\mathrm{NH}_{4}\right)_{2} \mathrm{SO}_{4}$. The column was washed with the same buffer, and retained proteins were eluted with linear gradient of $\left(\mathrm{NH}_{4}\right)_{2} \mathrm{SO}_{4}(1-0 \mathrm{M})$ in $0.05 \mathrm{M}$ Tris, $\mathrm{pH} 7.0$, at a flow rate of $2 \mathrm{~mL} / \mathrm{min}$. Fractions of $2 \mathrm{~mL}$ were manually collected. Active fractions were pooled, dialyzed against deionized water, and freeze-dried.

Freeze-dried proteins were solubilized with $\mathrm{TBS} / \mathrm{Ca}^{2+}$ at a concentration of $5 \mathrm{mg} / \mathrm{mL}$. After centrifugation, $1 \mathrm{~mL}$ was injected into a Sephacryl S-300 HR 16/60 column $(1.6$ x $60.0 \mathrm{~cm})$ coupled to an ÄKTA purifier system. The column was equilibrated and eluted with TBS at a flow rate of $1 \mathrm{~mL} / \mathrm{min}$. Chromatography was monitored at 280 $\mathrm{nm}$, and 3-mL fractions were collected.

EFFECTS OF PH, TEMPERATURE AND CATIONS ON

HemagGLUtinating/Hemolytic ACTIVITy OF

CVL-2 AND HGL

The effect of $\mathrm{pH}$, temperature and divalent ions on hemagglutinating/hemolytic activity was evaluated following Sampaio et al. (1998).

Molecular Mass Estimation OF HGL AND CVL-2

Sodium dodecyl sulfate polyacrylamide $(10 \%$ and $15 \%$ ) gel electrophoresis (SDS-PAGE), in the absence and presence of $\beta$-mercaptoethanol, was conducted as described by Laemmli (1970). The molecular mass of lectin and its subunits was estimated by comparing mobility of the bands with the following protein markers $(\mathrm{kDa})$ : Bovine serum albumin $(\mathrm{Mr}$ 67), Ovalbumin ( $\mathrm{Mr} 43$ ), Carbonic anhydrase ( $\mathrm{Mr}$ 29) Ribonuclease ( $\mathrm{Mr}$ 13.7) and Aprotinin ( $\mathrm{Mr}$ 6.5). Proteins were detected by staining with $0.1 \%$ Coomassie brilliant blue R-250.

The native molecular mass of HGL was estimated by size exclusion chromatography on a TSKgel G3000SWXL $(1.28 \times 30 \mathrm{~cm})$ column calibrated with the following protein markers $(\mathrm{kDa})$ : Conalbumin (Mr 74), Ovalbumin (Mr 43), Carbonic anhydrase (Mr 29), Ribonuclease (Mr 13.7) and Aprotinin (Mr 6.5).

The native molecular mass of CvL-2 was estimated by size exclusion chromatography on a Sephacryl S-300 HR 16/60 column (1.6 x 60.0 $\mathrm{cm}$ ) calibrated with protein markers (Conalbumin, Ovalbumin, Carbonic anhydrase, Ribonuclease and Aprotinin). Native PAGE (N-PAGE) was also performed to estimate native molecular mass of CvL-2. The native molecular mass of CvL-2 on native PAGE was estimated by comparing mobility of the band with the following protein markers (kDa): Thyroglobulin (669), Ferritin (440), Catalase (232), Lactate dehydrogenase (140), and BSA (66).

\section{LETHALITY TEST IN ARTEMIA}

Lethality test on Artemia nauplii was performed in accordance to pre-established methods (Carneiro et al. 2013).

Aqueous extracts of $C$. varians and $H$. grisea were dialyzed and freeze-dried. Extracts were prepared by homogenization with artificial sea water (ASW) at a concentration of $5 \mathrm{mg} / \mathrm{mL}$. The purified lectins were solubilized in ASW at $1 \mathrm{mg} / \mathrm{mL}$.

The tests were done on board 24-well Limbro plates such that each well contained $2 \mathrm{~mL}$ of artificial sea water (ASM) with 10 nauplii. Specific volumes of samples were added to each well to 
obtain concentrations of $10,25,50$ and $100 \mu \mathrm{g} / \mathrm{mL}$ for each sample. The experiments were performed in triplicate with control containing only $2 \mathrm{~mL}$ of ASW and 10 nauplii. Dead nauplii were counted after $24 \mathrm{~h}$. From these data, we calculated the percentage of deaths for each concentration and $\mathrm{LC}_{50}$ values were determined by probit analysis, as described by Finney (1971).

\section{RESULTS}

LECTIN AND HEMOLYTIC ACTIVITY OF MARINE INVERTEBRATE

\section{AQueOUS EXTRACTS}

Twenty species of marine invertebrates were screened for their hemagglutinating/hemolytic activity, and the results are shown in Table I.
Eight of the nine species of sponges tested, exhibited hemagglutinating activity, and all species showed preference for some group/treatment of blood, suggesting the presence of lectin like molecules.

Species of the genus Holothuria showed both hemagglutinating and hemolytic activities. After agglutination, rapid hemolysis was observed. However, hemolysis was able to be halted by crude extract precipitation with 1 vol of acetone. In the extracts of the marine sponge Amphimedon viridis and the mollusk Ischinachiton pectinatus, hemolysis was also observed, but it could not be stopped.

Among the twenty species tested, we selected the two most abundant species, $C$. varians and $H$. grisea, for lectin purification and toxicity assay.

TABLE I

Screening of aqueous extracts of 20 marine invertebrate species from the Brazilian coast for hemagglutinating/ hemolytic activity. Hemagglutinating activity is described in titer. $\mathrm{N}$-native erythrocytes; T-trypsin-treated erythrocytes; P-papain-treated erythrocytes; L-hemolytic activity observed.

\begin{tabular}{|c|c|c|c|c|c|c|c|c|c|c|c|c|}
\hline & \multicolumn{3}{|c|}{ Rabbit } & \multicolumn{3}{|c|}{ Human A type } & \multicolumn{3}{|c|}{ Human B type } & \multicolumn{3}{|c|}{ Human O type } \\
\hline & $\mathbf{N}$ & $\mathbf{T}$ & $\mathbf{P}$ & $\mathbf{N}$ & $\mathbf{T}$ & $\mathbf{P}$ & $\mathbf{N}$ & $\mathbf{T}$ & $\mathbf{P}$ & $\mathbf{N}$ & $\mathbf{T}$ & $\mathbf{P}$ \\
\hline \multicolumn{13}{|l|}{ PORIFERA } \\
\hline Aaptos sp. & $2^{6}$ & $2^{6}$ & $2^{6}$ & $2^{1}$ & $2^{2}$ & $2^{2}$ & - & - & - & - & - & - \\
\hline Amphimedon viridis & $\mathrm{L}$ & $\mathrm{L}$ & $\mathrm{L}$ & $\mathrm{L}$ & $\mathrm{L}$ & $\mathrm{L}$ & $\mathrm{L}$ & $\mathrm{L}$ & $\mathrm{L}$ & $\mathrm{L}$ & $\mathrm{L}$ & $\mathrm{L}$ \\
\hline Aplysina fulva & $2^{10}$ & $2^{12}$ & $2^{11}$ & $2^{8}$ & $2^{8}$ & $2^{8}$ & $2^{8}$ & $2^{8}$ & $2^{8}$ & $2^{8}$ & $2^{8}$ & $2^{8}$ \\
\hline Callyspongia sp. & $2^{8}$ & $2^{8}$ & $2^{8}$ & $\mathrm{~L}$ & $\mathrm{~L}$ & $\mathrm{~L}$ & $\mathrm{~L}$ & $\mathrm{~L}$ & $\mathrm{~L}$ & $\mathrm{~L}$ & $\mathrm{~L}$ & $\mathrm{~L}$ \\
\hline Cliona varians & $2^{3}$ & $2^{6}$ & $2^{6}$ & $2^{2}$ & $2^{5}$ & $2^{5}$ & - & $2^{1}$ & $2^{1}$ & - & - & - \\
\hline Haliclona caerulea & $2^{6}$ & $2^{6}$ & $2^{6}$ & $2^{4}$ & $2^{4}$ & $2^{4}$ & $2^{4}$ & $2^{4}$ & $2^{4}$ & $2^{4}$ & $2^{4}$ & $2^{4}$ \\
\hline Haliclona manglaris & $2^{6}$ & $2^{6}$ & $2^{6}$ & $2^{4}$ & $2^{4}$ & $2^{4}$ & $2^{4}$ & $2^{4}$ & $2^{4}$ & $2^{4}$ & $2^{4}$ & $2^{4}$ \\
\hline Haliclona melana & $2^{6}$ & $2^{2}$ & $2^{2}$ & - & - & - & - & - & - & - & - & - \\
\hline Spongorites sp. & $2^{6}$ & $2^{6}$ & $2^{6}$ & $2^{1}$ & $2^{1}$ & $2^{1}$ & - & - & - & - & - & - \\
\hline \multicolumn{13}{|l|}{ CNIDARIA } \\
\hline Protpalythoa variabilis & $2^{5}$ & $2^{5}$ & $2^{5}$ & $2^{5}$ & $2^{5}$ & $2^{5}$ & $2^{4}$ & $2^{5}$ & $2^{5}$ & $2^{4}$ & $2^{4}$ & $2^{3}$ \\
\hline Zoanthus sociatus & - & - & - & - & - & - & - & - & - & - & - & - \\
\hline \multicolumn{13}{|l|}{ MOLLUSCA } \\
\hline Ischinachiton pectinatus & $\mathrm{L}$ & $\mathrm{L}$ & $\mathrm{L}$ & $\mathrm{L}$ & $\mathrm{L}$ & $\mathrm{L}$ & $\mathrm{L}$ & $\mathrm{L}$ & $\mathrm{L}$ & $\mathrm{L}$ & $\mathrm{L}$ & $\mathrm{L}$ \\
\hline Littorina ziczac & - & - & - & - & - & - & - & - & - & - & - & - \\
\hline Pleuroploca sp. & - & - & - & - & - & - & - & - & - & - & - & - \\
\hline Turbinella laevigata & - & $2^{1}$ & - & - & - & - & - & - & - & - & - & - \\
\hline Voluta ebrea & - & - & - & - & - & - & - & - & - & - & - & - \\
\hline \multicolumn{13}{|l|}{ CRUSTACEA } \\
\hline Callinectes danae & $2^{4}$ & $2^{5}$ & $2^{5}$ & $2^{3}$ & $2^{4}$ & $2^{4}$ & $2^{3}$ & $2^{4}$ & $2^{4}$ & $2^{2}$ & $2^{2}$ & $2^{2}$ \\
\hline \multicolumn{13}{|l|}{ ECHINODERMATA } \\
\hline Echinometra lucunter & $2^{10}$ & $2^{10}$ & $2^{10}$ & $2^{8}$ & $2^{8}$ & $2^{8}$ & $2^{8}$ & $2^{8}$ & $2^{8}$ & $2^{8}$ & $2^{8}$ & $2^{8}$ \\
\hline Holothurea arenicola & $\mathrm{L}$ & $\mathrm{L}$ & $\mathrm{L}$ & $\mathrm{L}$ & $\mathrm{L}$ & $\mathrm{L}$ & $\mathrm{L}$ & $\mathrm{L}$ & $\mathrm{L}$ & $\mathrm{L}$ & $\mathrm{L}$ & $\mathrm{L}$ \\
\hline Holothurea grisea & $\mathrm{L}$ & $\mathrm{L}$ & $\mathrm{L}$ & $\mathrm{L}$ & $\mathrm{L}$ & $\mathrm{L}$ & $\mathrm{L}$ & $\mathrm{L}$ & $\mathrm{L}$ & $\mathrm{L}$ & $\mathrm{L}$ & $\mathrm{L}$ \\
\hline
\end{tabular}


PURIFICATION OF HEMOLYTIC LECTIN FROM HOLOTHURIA

GRISEA

The crude extract of $H$. grisea showed a higher level of hemagglutinating/hemolytic activity to all tested erythrocytes. After extract partition with n-butanol and ethanol, hemagglutinating/hemolytic activity was concentrated in Fraction 2 (F2). Thus, F2 was submitted to size-exclusion chromatography on TSKgel, where peak 1 corresponded to the pure hemolytic lectin HGL (Fig.1). This process resulted in purification of $35 \%$ with a $53 \%$ yield (Table II).

\section{PURIFICATION OF THE NEW LECTIN FROM CLIONA VARIANS}

The crude extract of $C$. varians was found to have strong hemagglutinating activity against trypsintreated rabbit erythrocytes. CvL-2, a new lectin from $C$. varians, was purified by a combination

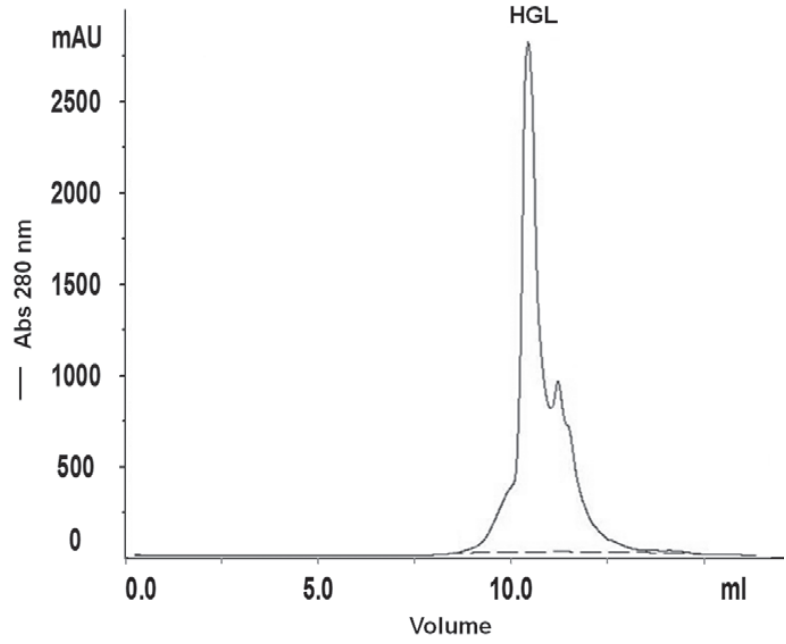

Figure 1 - Purification of HGL. TSKgel profile of F2 from $H$. grisea. Approximately $0.5 \mathrm{mg}$ of F2 was applied to the column previously equilibrated with TBS $\mathrm{pH} 7.6$, and fractions (1.0 $\mathrm{mL}$ each) were monitored at $280 \mathrm{~nm}$. The hemolytic activity was detected in the presence of $3 \%$ rabbit erythrocytes.

TABLE II

Purification processes of HGL. MHC - Minimum hemolytic concentration.

\begin{tabular}{lccccccc}
\hline Fractions & Total protein $(\mathbf{m g})$ & Titer & H.U./mg & Total activity & Purification & Yield $(\%)$ & MHC $(\boldsymbol{\mu g} / \mathbf{m L})$ \\
\hline Crude extract & 271.1 & 128 & 114.5 & 31040 & 1 & 100 & 8.75 \\
F2 & 28.8 & 256 & 595.3 & 17152 & 5.2 & 55.3 & 1.68 \\
TSK & 4.1 & 2048 & 4079.7 & 16588.8 & 35.6 & 53.4 & 0.24 \\
\hline
\end{tabular}
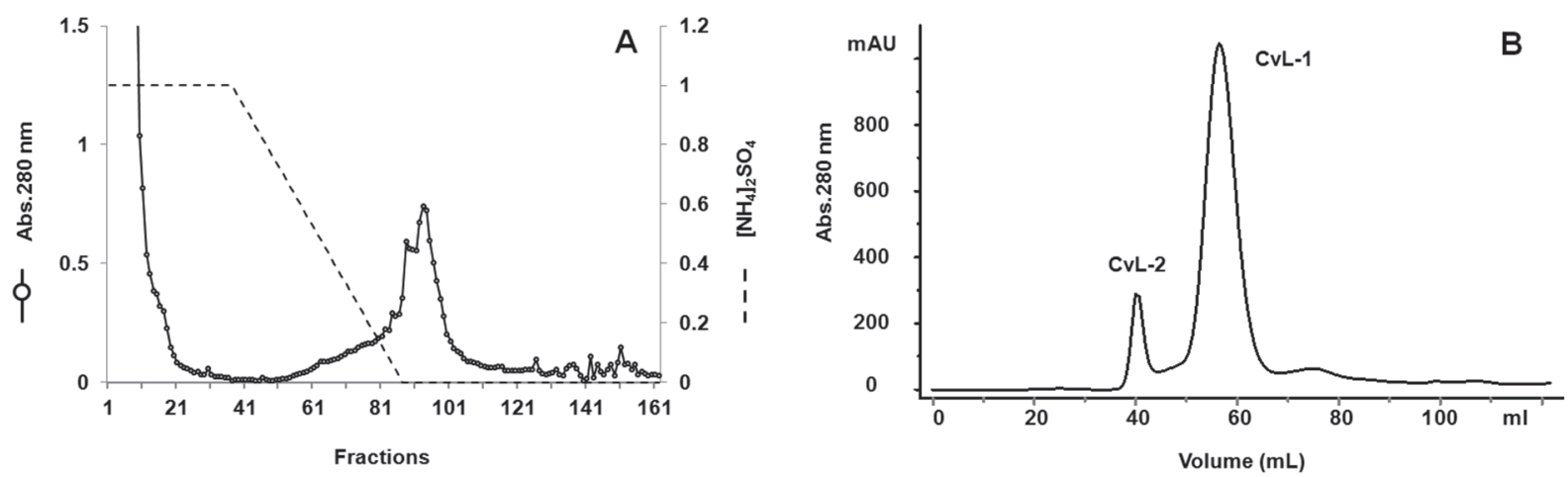

Figure 2 - Purification of CvL-2. (A) Phenyl Sepharose 6B chromatography profile. Approximately $100 \mathrm{mg}$ of CvL-enriched fraction were applied to the column $(1.0 \times 6.0 \mathrm{~cm})$ equilibrated with Tris/ $\left(\mathrm{NH}_{4}\right)_{2} \mathrm{SO}_{4}$. The lectin was eluted with linear gradient of $\left(\mathrm{NH}_{4}\right)_{2} \mathrm{SO}_{4}(1-0 \mathrm{M})$ in $0.05 \mathrm{M}$ Tris, $\mathrm{pH} 7.0$, and fractions $(2.0 \mathrm{~mL}$ each) were monitored at $280 \mathrm{~nm}$. The hemagglutinating activity was detected in the presence of $3 \%$ rabbit trypsin-treated erythrocytes (B) Size exclusion chromatography on Sephacryl S300 profile. Approximately $5 \mathrm{mg}$ of proteins retained on Phenyl-Sepharose were applied to the column equilibrated with TBS/ $\mathrm{Ca}^{2+}, \mathrm{pH} 7.6$, and fractions $(3.0 \mathrm{~mL}$ each) were monitored at $280 \mathrm{~nm}$. The hemagglutinating activity was detected in the presence of $3 \%$ trypsin-treated rabbit erythrocytes. 
of acetone precipitation, hydrophobic interaction chromatography (Fig. 2A) and size-exclusion chromatography (Fig. 2B). Compared to the activity in crude extract, the specific lectin activity was increased 21 times by purification procedure. Purified CvL2 represented $4.5 \%$ of the total HA of the extract (Table III). This procedure also resulted in the copurification of another lectin from $C$. varians: CvL-1 (Fig. 2B). CvL-1 was purified 60 times from the crude extract and represented $48 \%$ of total HA of the extract (Table III).
Molecular Mass Estimation of the PURIFIEd Lectins

The apparent molecular mass of the purified native HGL was estimated by gel filtration on calibrated TSKgel G3000SWXL column. It was calculated as $17 \mathrm{kDa}$ (data not shown). In addition, on SDSPAGE, under reducing and nonreducing conditions, HGL showed an apparent molecular mass of 15 $\mathrm{kDa}$ (Fig. 3A). These results suggest that HGL is a monomeric lectin, devoid of intermolecular disulfide bonds. On the other hand, native CvL-2 is a $465 \mathrm{kDA}$ protein by native PAGE (Fig. 3B). On

TABLE III

Purification processes of CvL-2. MAC - Minimum agglutinating concentration.

\begin{tabular}{lccccccc}
\hline Fractions & $\begin{array}{c}\text { Total protein } \\
(\mathbf{m g})\end{array}$ & Titer & H.U./mg & Total activity & Purification & Yield (\%) & $\begin{array}{c}\text { MAC } \\
(\boldsymbol{\mu g} / \mathbf{m L})\end{array}$ \\
\hline Crude Extract & 166 & 256 & 154.2 & 25600 & 1 & 100 & 6.48 \\
CvL-enriched fraction & 19.35 & 512 & 1190.7 & 23040 & 7.7 & 90 & 0.84 \\
Phenyl-Sepharose & 1.76 & 1024 & 12800 & 22528 & 83 & 88 & 0.08 \\
Sephacryl S-300 (CvL-2) & 0.36 & 128 & 3200 & 1152 & 20.7 & 4.5 & 0.31 \\
Sephacryl S-300 II (CvL-1) & 1.32 & 1024 & 9309.1 & 12288 & 60.3 & 48 & 0.11 \\
\hline
\end{tabular}
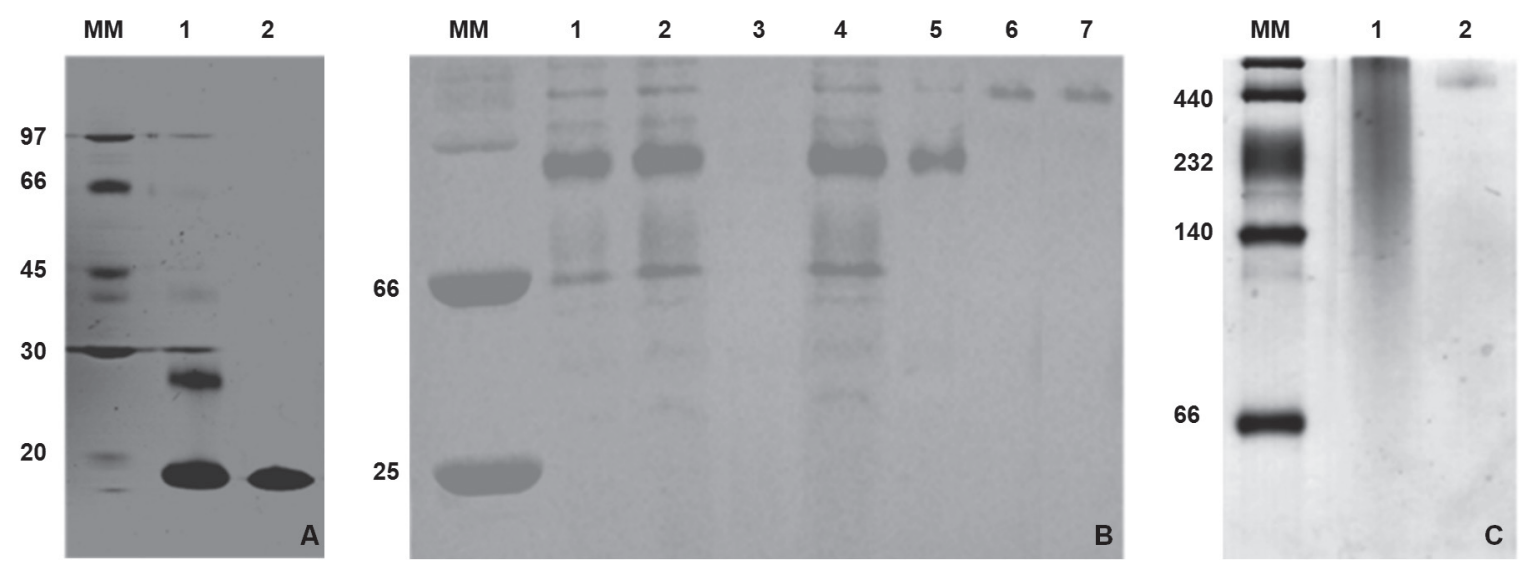

Figure 3 - Electrophoresis profile of purified lectins. (A) SDS-PAGE $15 \%$ analysis of (M) Molecular Weight Markers: 1) H. grisea crude extract; 2) Fraction 2; 3) HGL in the presence of $\beta$-mercaptoethanol. (B) SDS-PAGE $10 \%$ analysis of (M) Molecular Weight Markers: 1) C. varians crude extract; 2) CvL-enriched fraction; 3) precipitated proteins with $\left(\mathrm{NH}_{4}\right)_{2} \mathrm{SO}_{4} 1 \mathrm{M}$; 4) Retained fractions on Phenyl Sepharose; 5) CvL-2; 6) CvL-2 in the presence of $\beta$-mercaptoethanol. (C) Native PAGE (7.5\% acrylamide) analysis of (M) Molecular Weight Markers: 1) C. varians crude extract and 2) CvL-2. Proteins were stained with Coomassie blue and then with silver.

size-exclusion, CvL-2 was eluted in void-volume, suggesting a molecular mass higher than 1,000 $\mathrm{kDa}$ (data not shown). SDS PAGE of purified lectin showed a single band of $175 \mathrm{kDa}$, under reducing and nonreducing conditions (Fig. 3C). These data suggest that CvL-2 presents anomalous behavior. While appears as a trimeric protein on N-PAGE, it shows multimeric form on size-exclusion chromatography. 
HEMAGGLUTINATING AND INHIBITION ASSAYS OF PURIFIED LECTINS

HGL quickly hemolyzed all tested erythrocytes. However, at the beginning of the hemolysis process, it was possible to observe the agglutination of erythrocytes. We were unsuccessful in achieving the inhibition of hemolytic activity with sugars, therefore, we conducted an osmotic protection assay. With this procedure, it was possible to observe that the dextrose was able to protect against erythrocyte lysis at the last dilution of HGL. This allowed us to visualize the agglutination by optical microscopy (Fig. 4) and perform the inhibition test. Hemagglutinating activity of HGL was inhibited by PSM and fetuin with minimal inhibitory concentration (MIC) at $0.31 \mathrm{mg} / \mathrm{mL}$ and $2.5 \mathrm{mg} /$ $\mathrm{mL}$, respectively (Table IV).
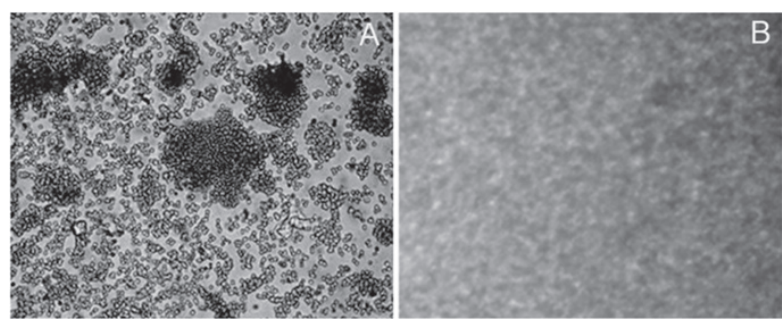

Figure 4 - Hemagglutinating activity of HGL under osmotic protection with $5.5 \%$ dextrose. A) Hemagglutinating of rabbit erythrocytes treated with trypsin in the presence of HGL; B) Control group: erythrocytes in saline.

CvL-2 strongly agglutinates trypsin-treated rabbit erythrocytes and, to a lesser degree, trypsin-treated human erythrocytes derived from blood type A. Hemagglutinating activity of CvL2 was inhibited by galactosides and porcine stomach mucin (PSM). GalNAc and PSM were potent inhibitors of CvL-2 activity with MIC at $0.2 \mathrm{mM}$ and $9.7 \mu \mathrm{g} / \mathrm{mL}$, respectively. Galactose $(\mathrm{MIC}=12.5 \mathrm{mM}), \alpha$-methyl-D-galactopyranoside $(\mathrm{MIC}=6.25 \mathrm{mM})$ and lactose $(\mathrm{MIC}=3.1 \mathrm{mM})$ were all able to inhibit CvL-2 (Table IV).
TABLE IV

Inhibition of hemagglutinating activity of the purified lectins. The initial concentrations were $100 \mathrm{mM}$ and $5 \mathrm{mg} / \mathrm{mL}$ for sugars and glycoprotein, respectively.

\begin{tabular}{lcc}
\hline Sugars & $\begin{array}{c}\text { CvL-2 } \\
\left(\mathbf{M I C} \boldsymbol{*}^{*}\right.\end{array}$ & $\begin{array}{c}\text { HGL } \\
(\mathbf{M I C})^{*}\end{array}$ \\
\hline D-Galactose & $12.5 \mathrm{mM}$ & $\mathrm{NI}$ \\
D-Glucose & $\mathrm{NI}$ & $\mathrm{NI}$ \\
D-Mannose & $\mathrm{NI}$ & $\mathrm{NI}$ \\
D-Arabinose & $\mathrm{NI}$ & $\mathrm{NI}$ \\
D-Frutose & $\mathrm{NI}$ & $\mathrm{NI}$ \\
Methyl- $\alpha$-D-Galactopiranoside & $6.25 \mathrm{mM}$ & $\mathrm{NI}$ \\
Methyl- $\alpha$-D-Glucopiranoside & $\mathrm{NI}$ & $\mathrm{NI}$ \\
D-GalNAc & $0.2 \mathrm{mM}$ & $\mathrm{NI}$ \\
D-GlcNAc & $\mathrm{NI}$ & $\mathrm{NI}$ \\
D-Lactulose & $\mathrm{NI}$ & $\mathrm{NI}$ \\
D-Sucrose & $\mathrm{NI}$ & $\mathrm{NI}$ \\
$\alpha$-D-Lactose & $3.1 \mathrm{mM}$ & $\mathrm{NI}$ \\
\hline Glycoproteins & & \\
\hline PSM & $9.7 \mu \mathrm{g} \cdot \mathrm{ml}^{-1}$ & $0.31 \mathrm{mg} \cdot \mathrm{ml}^{-1}$ \\
Tyroglobulin & $\mathrm{NI}$ & $\mathrm{NI}$ \\
Ovomucoid & $\mathrm{NI}$ & $\mathrm{NI}$ \\
Fetuin & $\mathrm{NI}$ & $2.5 \mathrm{mg} \cdot \mathrm{ml}^{-1}$ \\
Orosomucoid & $\mathrm{NI}$ & $\mathrm{NI}$ \\
\hline
\end{tabular}

EFFECTS OF PH, TEMPERATURE AND DIVALENT CATIONS

Hemolytic activity of HGL was not inhibited when previously treated with EDTA. Although we added the divalent cations $\mathrm{Ca}^{2+}, \mathrm{Mg}^{2+}$ and $\mathrm{Mn}^{2+}$, no change in protein activity was observed. HGL hemolytic activity was stable in all ranges of tested $\mathrm{pH}$ (4-10). HGL exhibited high thermostability. The hemolytic activity was unaffected after exposure of the lectin at $90{ }^{\circ} \mathrm{C}$, and after $1 \mathrm{~h}$ at $100{ }^{\circ} \mathrm{C}$, the activity decreased to $50 \%$.

Hemagglutinating activity of $\mathrm{CvL}-2$ was completely abolished after dialysis against EDTA. The activity of the lectin was restored when EDTA was removed and $5 \mathrm{mM} \mathrm{CaCl}$ was added to the protein solution. The lectin activity of CvL-2 was optimum on neutral $\mathrm{pH}$ (7). The activity rapidly decreased when the lectin was incubated in basic or acidic $\mathrm{pH}$. CvL-2 showed relative thermostability. Its activity was stable at $50{ }^{\circ} \mathrm{C}$, but gradually decreased with increasing temperature. At $90{ }^{\circ} \mathrm{C}$, the activity remained at $25 \%$, but it was completely abolished at $100{ }^{\circ} \mathrm{C}$. 
Toxic EFFECTs of CRUde Extracts AND LeCtins PURIFIED FROM C. VARIANS AND H. GRISEA

Extracts from $C$. varians and $H$. grisea showed different levels of toxicity on Artemia nauplii. Crude extract of $H$. grisea was very toxic $\left(\mathrm{LC}_{50}=\right.$ $8.1 \pm 3.0 \mu \mathrm{g} / \mathrm{mL}$ ), whereas crude extract of C. varians showed low toxicity $\left(\mathrm{LC}_{50}=116 \pm 23.3 \mu \mathrm{g} / \mathrm{mL}\right)$. The toxic effects were observed to be dose-dependent. The lectins HGL and CvL-1 showed potent activity against Artemia nauplii. $\mathrm{LC}_{50}$ values obtained were $9.5 \mu \mathrm{g} / \mathrm{mL}$ and $5.6 \mu \mathrm{g} / \mathrm{mL}$, respectively. However, CvL-2 showed no toxicity against Artemia nauplii $\left(\mathrm{LC}_{50}=850.1 \pm 3.4 \mu \mathrm{g} / \mathrm{mL}\right)$.

\section{DISCUSSION}

In at least twelve tested species, hemagglutinating activity was different for different blood types, suggesting the presence of lectin-like molecules in these species; namely, hemagglutinating activity was observed in $60 \%$ of the tested species. This value is similar to those found in other screenings of hemagglutinating/hemolytic activity of marine invertebrates (Dresch et al. 2005, Mojica et al. 2005). Furthermore, while hemolytic molecules, for the most part remain unknown, hemolytic activity was found in the extracts of some studied species, and HGL; which seems to be a hemolytic agent, was isolated in Holothurea grisea.

Toxic activity is a common factor among lectins (Pajic et al. 2002, Queiroz et al. 2008, Santos et al. 2010). Similar to lectins isolated from Haliclona caerulea (Carneiro et al. 2013), Axinella corrugata (Dresch et al. 2011) and Aplysia kurodai (Kawsar et al. 2010), HGL showed a high level of cytotoxicity against Artemia nauplii. However, hemolysis caused by lectin is rare, and few lectins have shown hemolytic activity (Hatakeyama et al. 1994, Sudhakar and Vincent 2014). The lectin isolated from the sea cucumber Cucumaria echinata (CELIII) showed both hemolytic and toxic activities (Hatakeyama et al. 1994, Oda et al. 1997). CELIII is an R-type lectin that is $\mathrm{Ca}^{2+}$-dependent and
gal/galNAc-binding (Nakano et al. 1999). These activities are mediated by binding of the protein to the specific carbohydrate chain on the target cells, followed by the formation of ion-permeable pores in the cell membrane through protein oligomerization (Hatakeyma et al. 1995). We were not able to determine the mechanism which mediates HGLinitiated hemolysis. However, both the agglutination of erythrocytes after osmotic protection and the HGL inhibition by PSM, indicated that the binding of HGL to carbohydrates in the erythrocyte membranes is the first step in hemolytic activity.

HGL showed singular stability, maintaining its activity in a broad range of $\mathrm{pH}$ and temperature. Usually, lectins from marine invertebrates possess optimal activity on basic-neutral $\mathrm{pH}$ and thermal stability up to temperatures of $70{ }^{\circ} \mathrm{C}$.

Lectins isolated from sea cucumbers are generally ion-dependent proteins, many of which sharing structural factors that allow them to be grouped into the C-type super family (Himeshima et al. 1994, Hatakeyama et al. 2002), but HGL could not be grouped into the C-type super family . In general, C-type lectins bind to monosaccharides, such as mannose and galactose. HGL is not an iondependent lectin and does not bind to galactose or mannose. On the other hand, CvL-2 could be inhibited by EDTA, indicating that CvL-2 activity was $\mathrm{Ca}^{2+}$-dependent. Lectins isolated from the sponges Aplysina lawnosa, Aplysina archeri and Aphrocallistes vastus also presented $\mathrm{Ca}^{2+}$ dependent activity (Miarrons and Fresno 2000, Gundacker et al. 2001). However, it is impossible to define CvL-2 as a C-type lectin without knowledge of its primary structure.

Like CvL-2, a considerable number of lectins isolated from marine sponges, agglutinate proteasetreated rabbit erythrocytes (Miarrons and Fresno 2000, Pajic et al. 2002, Dresch et al. 2008). CvL2 was inhibited by diverse galactosides and PSM. Similar to CvL-1, CvL-2 was inhibited by galactose, but to a lesser degree (Moura et al. 2006). Moreover, 
CvL-2 was inhibited by lactose at $\mathrm{MIC}=3.1 \mathrm{mM}$, whereas $\mathrm{CvL}-1$ showed $\mathrm{MIC}=25 \mathrm{mM}$ to some disaccharides (Moura et al. 2006). CvL-1 showed a slight affinity to glucose and its derivatives (Moura et al. 2006), but CvL-2 did not. The inhibition test for both lectins suggests that C-4 hydroxyl represents a point of differential recognition for CvL-1 and CvL-2. For CvL-2, C-4 hydroxyl likely interacts directly with $\mathrm{CRD}$, participating in recognition, since galactose, but not glucose, was able to inhibit the activity of CvL-2. GalNAc was the powerful inhibitor for CvL-2 activity, most likely because the presence of $\mathrm{N}$-Acetyl group increases the number of interactions between CvL-2 CRD and sugar. In fact, several lectins from marine invertebrates have presented affinity to GalNAc (Belogortseva et al. 1998, Beisel et al. 1999).

Molecular mass of CvL-2 in electrophoresis suggests a trimeric conformation $(465 \mathrm{kDa})$. Several quaternary arrangements have been reported in sponge lectins: dimeric (Pajic et al. 2002), trimeric (Xiong et al. 2006), tetrameric (Miarrons and Fresno 2000) and multimeric (Medeiros et al. 2010) proteins linked by weak interactions or disulfide bonds were described.

Furthermore, similar to other lectins from marine invertebrates (Moura et al. 2006, Dresch et al. 2008), optimal activity of CvL-2 was observed in neutral $\mathrm{pH}$, probably because that $\mathrm{pH}$ represents the natural environment of sponges.

Many extracts of aquatic organisms have been tested against Artemia nauplii and showed toxic activities (Thompson et al. 1985, Carbalho et al. 2002). Some of these compounds have already been isolated and evaluated in other models. The results have shown a range of biological activities, such as anticancer, suppression of the HIV virus, anti-inflammatory and proinflammatory activity (Herencia et al. 1998, McCune et al. 1989). In a previous study, CvL-1 was able to inhibit the growth of human leukemia cells, triggering the signaling of programmed cell death (Queiroz et al.
2008). CvL-1 also showed a high level of toxicity against Artemia nauplii. The new lectins isolated in this work showed different levels of toxicity to Artemia nauplii. HGL was highly toxic and could, like CvL-1, be a powerful biotechnology tool in cancer research. On the other hand, CvL-2 showed low toxicity effects and is expected to have no effect on malignant cells and inflammatory response.

In summary, hemagglutinating activity was observed in about $60 \%$ of tested species, indicating that marine invertebrates from the Brazilian coast are a rich and untapped source of new lectins. Furthermore, two new lectins were isolated, and one, HGL, is a rare lectin with hemolytic activity. Thus, our cataloging of lectin activity on marine invertebrates leads us to novel features associated with these marine organisms from a biotechnological perspective.

\section{ACKNOWLEDGMENTS}

This work was supported by the Brazilian agencies Conselho Nacional de Desenvolvimento Científico e Tecnológico (CNPq), Fundação Cearense de Apoio ao Desenvolvimento Científico e Tecnológico (FUNCAP) and Financiadora de Estudos e Projetos (FINEP). The authors are grateful to Msc. Sula Salani for the identification of the sponges. AHS, BSC, CSN adn $\mathrm{KSN}$ are senior investigators of $\mathrm{CNPq}$.

\section{RESUMO}

Vinte espécies de invertebrados marinhos, coletados na costa brasileira, foram avaliados quanto à presença de atividade hemaglutinante/hemolítica. Em pelo menos doze espécies testadas, a atividade hemaglutinante foi diferencial para diferentes grupos sanguíneos, sugerindo a presença de lectinas. Extratos de quatro espécies apresentaram atividade hemolítica. Duas novas lectinas foram purificadas da esponja marinha Cliona varians (CvL-2) e do pepino-domar Holothuria grisea (HGL). CvL2 foi capaz de aglutinar eritrócitos de coelho e foi inibida por galactosídeos. A atividade hemaglutinante foi estável em $\mathrm{pH}$ neutro e temperaturas abaixo de $70{ }^{\circ} \mathrm{C}$. CvL-2 é uma 
proteína trímero com subunidades de $175 \mathrm{kDa}$. Por outro lado, HGL apresentou atividade hemaglutinante e hemolítica em eritrócitos humanos e de coelho, mas a hemólise pôde ser inibida por proteção osmótica, enquanto que a aglutinação foi inibida por mucina. HGL mostrou-se estável em valores de $\mathrm{pH}$ de 4-10 e temperaturas até $90{ }^{\circ} \mathrm{C}$. Em eletroforeses e gel filtração, HGL foi uma proteína monômero de 15 kDa. CvL-2 e HGL mostraram diferentes níveis de toxicidade contra náuplios de Artemia. CvL-2 apresentou $\mathrm{LC}_{50}$ de $850,1 \mu \mathrm{g} / \mathrm{mL}$, enquanto que HGL apresentou $\mathrm{LC}_{50}$ de $9,5 \mu \mathrm{g} / \mathrm{mL}$.

Palavras-chaves: purificação, hemólise, citotoxicidade, galactose.

\section{REFERENCES}

Beisel HG, Kawabata S, Iwanaga S, Huber R and Bode W. 1999. Tachylectin-2: crystal structutre of a specific GlcNAc/GalNAc-binding lectin involved in the innate immunity host defense of the japanese horseshoe crab Tachypleus tridentatus. EMBO J 18(9): 2313-2322.

Belogortseva NI, Molchanova VI, Kurika AV, SKobun AS AND GLAZKOVA V. 1998. Isolation and characterization of new GalNAc/Gal specific lectin from the sea mussel Crenomytes grayanus. Comp Biochem Physiol C 119(1): 45-90.

Burgess JG. 2012. New and emerging analytical techniques for marine biotechnology. Curr Opin Biotech 23: 29-33.

Carballo JL, Hernández-Inda HL, PÉRez P ANd GarcíaGRÁVAlos MD. 2002. A comparison between two brine shrimp assays to detect in vitro cytotoxicity in marine natural products. BMC Biotechnol 2: 17.

CARneIRo RF ET AL. 2013. Halilectin 1 (H-1) and Halilectin 2 (H-2): two new lectins isolated from the marine sponge Haliclona caerulea. J Mol Recognit 26: 51-58.

Dresch RR, HAESER AS, LeRner C, Mothes B, VozariHAMPE MM AND HENRIQUES AT. 2005. Detecção da atividade lectínica e atividade hemolítica em estratos de esponjas (Porífera) nativas da costa atlântica do Brasil. Braz J Pharmacog 15(1): 16-22.

Dresch RR, LERner CB, Mothes B, TRINDAde VMT, HENRIQUES AT AND VOZARI-HAMPE MM. 2011. Biological activities of ACL-I and physicochemical properties of ACL-II, lectins isolated from the marine sponge Axinella corrugata. Comp Biochem Phys B 161: 365-370.

DRESCH RR, ZANETTI GD, LERNER CB, MOTHES B, TRINDADE VMT, HENRIQUES AT AND VOZARI-HAMPE MM. 2008. ACL-I, a lectin from the marine sponge Axinella corrugata: Isolation, characterization and chemotactic activity. Comp Biochem Phys C 148: 23-30.
FINNEY DJ. 1971. Probit analysis, $3^{\text {rd }}$ ed., Cambridge: University press, $242 \mathrm{p}$.

Gundacker D, Leys SP, SCHRÖDER HC, MÜlLER IM AND MÜLLER WEG. 2001. Isolation and cloning of a C-type lectin form the hexactinellid sponge Aphrocallistes vastus a putative aggregation factor. Glycobiology 11: 21-29.

HATAKEYAMA T, KOHZAKI H, NAGATOMO H AND YAMASAKI N. 1994. Purification and Characterization of Four $\mathrm{Ca}^{2+}$-Dependent Lectins from the Marine Invertebrate, Cucumaria echinata. J Biochem 116: 209-214.

Hatakeyama T, Matsuo N, Shiba K, Nishinohara S, YAMASAKI N, SUGAWARA H AND AOYAGI H. 2002. Amino acid sequence and carbohydrate-binding analysis of the $\mathrm{n}$ acetyl D galactosamine-specific C-type lectin, CEL-I, from the Holothuroidea, Cucumaria echinata. Biosci Biotechnol Biochem 66(1): 157-163.

Hatakeyama T, Nagatomo H AND Yamasaki N. 1995. Interaction of the hemolytic lectin CEL-III from the marine invertebrate Cucumaria echinata with the erythrocyte membrane. J Biol Chem 270: 3560-3564.

Herencia F, Ubeda A, Ferrándiz ML, TERENCIO MC, AlCARAZ MJ, CARRASCOSA M, CAPACCIONI R AND PAYÁ M. 1998. Anti-inflammatory activity in mice of extracts from mediterranean marine invertebrates. Life Sci 62: 115-120.

Himeshima T, Hatakeyama T AND YAmasaki N. 1994. Amino acid sequence of a lectin from the sea cucumber, Sthichopus japonicus, and its structural ralationship to the C-type animal lectin family. J Biochem 115(4): 689-692.

KAWSAR SMA, AFTABUDDIN S, YASUMITSU H AND OZEKI Y. 2010. The cytotoxic activity of two D-galactose-binding lectins purified from marine invertebrates. Arch Biol Sci 62(4): 1027-1034.

KILPATRICK DC. 2002. Animal lectins: a historical introduction and overview. Biochim Biophys Acta 157: 2187-2197.

Kuramoto M, ARImoto H AND UEmURA D. 2004. Bioactive alkaloids from the sea: A review. Mar Drugs 1: 39-54.

LAEMMLI UK. 1970. Cleavage of structural proteins during the assembly of the head of the bacteriophage T4. Nature 227: 680-683.

MCCunE JM, NAMIKAWA R, SHIH CC, RABIN L AND KANESHIMA H. 1989. Supression of HIV infection in AZTTreated SCID-hu Mice. Science 247: 564-565.

Medeiros DS, Medeiros TS, Ribeiro JKC, Monteiro NKV, Migliolo L, UchoA AF, VASCONCElos IM, Oliveira AS, SALES MP AND SANTOS EA. 2010. A lactose specific lectin from the sponge Cinachyrella apion: Purification, characterization, N-terminal sequences aligment and agglutinating activity on Leishmania promastigotes. Comp Biochem Physiol B 155: 211-216.

Melo AA ET AL. 2014. HGA-2, a novel galactoside-binding lectin from the sea cucumber Holothuria grisea binds to bacterial cells. Int J Biol Macromol 64: 435-442.

MiarRons PB AND Fresno M. 2000. Lectins from Tropical Sponges: Purification and characterization of lectins from genus Aplysina. J Biol Chem 275: 29283-29289. 
MoJICA ERE, DeOCARIS CC AND MERCA FE. 2005. A survey of lectin-like activity in philippine marine invertebrates. Philipp J Sci 134(2): 135-142.

Moura RM, Aragẽo K, Melo AA, CARneiro RF, Osorio C, LUZ P, ALENCAR L AND CAVADA BS. 2012. Holothuria grisea aglutinin (HGA): The first invertebrate lectin with anti-inflammatory effects. Fundam Clin Pharmacol 27(6): 656-668.

Moura RM, QueIroz AFS, MonTEIRo NKV, MOURA GEDD, MACEDO LLP, SANTOS EA AND SALES MP. 2006. CvL, a lectin from the marine sponge Cliona varians: Isolation, characterization and its effects on pathogenic bacteria and Leishmania promastigotas. Comp Biochem Physiol A 145: 517-523.

NaKano M, Tabata S, SUgIHARA K, KoUZuma Y, Kimura M AND YAMASAKI N. 1999. Primary structure of hemolytic lectin CEL-III from marine invertebrate Cucumaria echinata and its cDNA: Structural similarity to the B-chain from plant lectin, ricin. Biochim Biophys Acta 1435: 167-176.

OdA T, TSURU M, Hatakeyama T, NAGATOMO H, MURAMatSU T AND YAMASAKI N. 1997. Temperature and pH-dependent cytotoxic effect of the hemolytic lectin CEL-III from the marine invertebrate Cucumaria echinata on various cell lines. J Biochem 121: 560-567.

Ogawa T, Watanabe M, Naganuma T and Muramoto K. 2011. Diversified Carbohydrate-Binding Lectins from Marine Resources. Journal of Amino Acids, Article ID 838914, 20 p.

PajIC I, KlJajic Z, Dogovic N, SLAdic D, JuRAnIC Z AND GASIC MJ. 2002. A novel lectin from the sponge Haliclona cratera: isolation, characterization and biological activity. Comp Biochem Physiol C 132: 213-221.

QUEIROZ AFS ET AL. 2008. Growth inhibitory activity of a novel lectin from Cliona varians against K652 human erythroleukemia cells. Cancer Chemother Pharmacol 63: 1023-1033.

RASJASA OK, VASKE YM, NAVARRO G, VERVOORT HC, TENNEY K, Linington RG AND CREWS P. 2011. Highlights of marine invertebrate-derived biosynthetic products: Their biomedical potential and possible production by microbial associants. Biorg Med Chem 19(22): 6658-6674.
Ritchie RJ, GUY K AND PhILP JC. 2013. Policy to support marine biotechnology-based solutions to global challenges. Trends in Biotechnology 31(3): 128-131.

SAMPAIO AH, Rogers DJ AND BARWELL CJ. 1998. A galactose specific lectin from the red marine alga Ptilota filicina. Phytochemistry 48: 765-769.

SANTOS AF, CAVAdA BS, ROCHA BAM, NASCIMENTO KS AND SANT'ANA AEG. 2010. Toxicity of some glucose/ mannose-binding lectins to Biomphalaria glabrata and Artemia salina. Bioresource Technol 101(2): 1794-1798.

SHARON N AND LIS H. 2004. History of lectins: from hemagglutinins to biological recognition molecules. Glycobiology 14: 53R-62R.

SIPKEMA D, FRANSSEN MCR, OSINGA R, TRAMPER J AND WiJfFELS RH. 2005. Marine Sponges as Pharmacy. Mar Biotechnol 7: 142-162.

SUDHAKAR GRL AND VINCENT SGP. 2014. Purification and characterization of a novel C-type hemolytic lectin for clot lysis from the fresh water clam Villotorita cyprinoides: A possible natural throbotyc agent against myocardial infarction. Fish \& Shellfish Immun 36: 367-373.

THOMPSON JE, WALKER RP AND FAULKNER DJ. 1985. Screening and bioassays for biologically-active substances from forty marine sponge species from San Diego, California, USA. Mar Biol 88: 11-21.

Xiong C, Li W, Liu H, Zhang W, Dou J, Bai X, Du Y and MA X. 2006. A normal mucin-binding lectin from the sponge Craniella australiensis. Comp Biochem Phys C 143: 9-16.

Yoshida S, SHIMAda Y, KondoH D, Kouzuma Y, GHOSH AK, JACOBS-LORENA M AND SINDEN RE. 2007. Hemolytic C-Type lectin CEL-III from sea cucumber expressed in transgenic mosquitoes impairs malaria parasite development. PLoS Pathog 3(12): 1962-1970. 